\title{
CONTAMINATION OF CORN GROWING AREAS DUE TO INTENSIVE FERTILIZATION IN THE HIGH PLANE OF MEXICO
}

\author{
E. T. ROMERO GUZMÁN ${ }^{1, *}$, EN. ORDOÑEZ REGIL ${ }^{1}$, L. R. REYES GUTIÉRREZ ${ }^{2}$, \\ M. V. ESTELLER ALBERICH ${ }^{3}$, A. ROJAS HERNÁNDEZ ${ }^{4}$ \\ and ED. ORDOÑEZ REGIL ${ }^{1}$ \\ ${ }^{1}$ Departamento de Química, Gerencia de Ciencias Básicas. Instituto Nacional de Investigaciones \\ Nucleares. Carrereta México-Toluca km 36.5. C.P. 52045. A.P. 18-1027, México; ${ }^{2}$ Centro de \\ Investigaciones en Ciencias de la Tierra. Universidad Autónoma del Estado de Hidalgo. Carretera \\ Pachuca-Tulancingo Km. 4.5, Pachuca de Soto. C.P. 42184, Hidalgo, México; ${ }^{3}$ Centro \\ Interamericano de Recursos del Agua. Facultad de Ingeniería. Universidad Autónoma del Estado \\ de México. Cerro Coatepec. S/N. C.U. 50130 Toluca, Estado de México, México; ${ }^{4}$ Departamento de \\ Química Analítica. Universidad Autónoma Metropolitana. Unidad Iztapalapa. Av. San Rafael \\ Atlixco $N^{\circ}$ 186, Col. Vicentina C.P. 09340, Iztapalapa, México D.F. México \\ (*author for correspondence, e-mail: etrg@nuclear.inin.mx)
}

(Received 12 August 2005; accepted 19 February 2006)

\begin{abstract}
The agricultural activities practice often demands an intensive application of fertilizers. Phosphate and nitrogen fertilizers are the most employed in the corn growing areas of the central Mexico highlands. The first ones presents an uranium content ranging from 50 to $200 \mathrm{mg} \cdot \mathrm{kg}^{-1}$ depending on the origin of the phosphate rock used in its production. It is crucial to analyze the rainwater, surface water, soil water at several depths, groundwater and soil to determine the simultaneous behavior of phosphate, nitrate and uranium, and their leaching in a specific agricultural land. Uranium concentration, $16 \mathrm{mg} \cdot \mathrm{kg}^{-1}$, in the soil water was higher than that in the surface water and groundwater. The different concentrations are due to an unequal uranium distribution in the environment. The phosphate concentration, $37.4 \mathrm{mg} \cdot \mathrm{kg}^{-1}$, diminished throughout the profile of the soil due to a sorption-precipitation process. The nitrates were leached toward groundwater after the application of fertilizers, but the nitrate concentration in it did not exceed the limit for drinking water.
\end{abstract}

Keywords: leaching phosphate, nitrate and uranium through vadose zone, movement of nitrate, phosphate, uranium in water

\section{Introduction}

During the last 30 years, the unrestricted production and consumption of fertilizers in the world have been increasing considerably; this increment has led to a great production of feed essential for human survival. Yet, it has ensued a considerable concern about the possible environmental deterioration they could cause. This concern is centered on three main aspects: a) increase of phosphates and nitrates in the surface water, soil water and groundwater in agricultural areas (Vighi et al., 1991; Hall, 1992; Eghball et al., 1996), b) eutrophication of water bodies (He et al., 1995), and c) increment in the uranium concentration in land and in water resulting from the use of phosphated fertilizers (Barisic et al., 1992; Zielinski et al., 1997).

Water, Air, and Soil Pollution (2006) 175: 77-98

DOI: $10.1007 / \mathrm{s} 11270-006-9114-1$

(c) Springer 2006 
Phosphate fertilizers are made of soluble phosphate complexes that contain uranium, ranging between 50 and $200 \mathrm{mg} \cdot \mathrm{kg}^{-1}$ (Romero et al., 1995). These values are higher above the average uranium content in the earth's crust, which is of $1.8 \mathrm{mg} \cdot \mathrm{kg}^{-1}$ (Taylor and McClennan, 1985). The uranium is deposited in the soil together with the phosphates during the fertilization period. In time, the uranium and phosphorus are dispersed in the soil and they can be moved both by the runoff reaching the water bodies (rivers, lakes, reservoirs) and soil water until they reach the groundwater. This step plays an important role in the migration and redistribution of uranium in nature.

In the case of phosphorus, high concentrations in soils can cause adverse effects in the availability of some minor elements. In addition to being a source of surface and groundwater contamination when the phosphorus is carried to those water bodies. The movement of phosphorus through the soils after a phosphate fertilizer that has been applied is insignificant. However, phosphorus can move deeply into the soil, reaching the groundwater, at high phosphorus loading rates and repeating applications of fertilizer together with manured applications under favorable conditions (Egball et al., 1996), or when the soil fixation capacity has been completely saturated (Gerritsen, 1993).

Uranium is a trace constituent of many phosphate bearing fertilizers. The increase in its concentration found in most of the profiles of fertilized soil has been documented for decades (Rothbaumn et al., 1979). This is also the case for superficial water (runoff) or drainage coming from agricultural lands (Barisic et al., 1992; Zielinski et al., 1997). Uranium is recognized by the World Health Organization (1993) as a potentially harmful constituent of drinking water; the U.S. Environmental Protection Agency, USEPA (1996) proposed the implementation of a $20 \mu \mathrm{gL}^{-1}$ uranium drinking water quality standard. Likewise, the Mexican government established $1.44 \mathrm{mgL}^{-1}$ as the standard in the official regulations (Diario Oficial de la Federación, DOF, 1989). The migration of uranium in systems is largely controlled by uranium solution-mineral equilibria and sorption reactions. Uranyl complexes contain hydroxide, carbonate, fluoride, sulfate, nitrate or phosphate which can exist and even predominate depending on water conditions and soil properties.

In many world aquifers, where agricultural activities are intense, the ni-

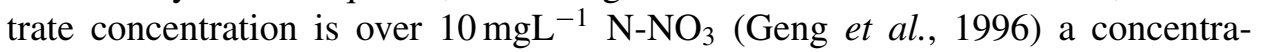
tion that is considered the acceptable limit for drinking water by the USEPA as well as by the Mexican norm (DOF, 1989). Nitrogen follows a cycle in which there is a series of transformation and transport mechanisms that affect the nitrogen chemical species (Frezze and Cherry, 1979). These mechanisms include physical processes (leaching), biological processes (plant assimilation, mineralization-immobilization, nitrification, denitrification) and physico-chemical processes (ammonium adsorption-fixation, volatilization). The nitrate fraction that is not utilized by the crop, incorporates itself into soil or denitrifies and it can leach through the vadose zone and reach the aquifer (Jabro et al., 1996). It can also be 
moved by runoff, and remain stored in water bodies where, along with phosphorous content, intensifies the eutrophication process (Sharpley et al., 1987).

Considering, the mentioned data, the nonpoint contamination of water bodies with phosphorus, uranium and nitrogen is now recognized as one of the major water quality risks. In the case under the present study, the agricultural land is located in the Toluca Valley aquifer, which is exploited in order to satisfy both the local water demand and that of Mexico City. Therefore, the aim of this work was two fold: a. to evaluate the effect of the agricultural practices on nitrogen, phosphorus and uranium levels in water and soil, studying the movement of these compounds through the soil, as well as b. to determine the degree of association that exists between the uranium and the other inorganic anions.

\section{Experimental}

\subsection{SITE DESCRIPTION}

The Toluca Valley is located in the highlands of Central Mexico at an average altitude of $2600 \mathrm{~m}$ above the sea level (Figure 1); the Lerma river (upper course of the Lerma river) runs through it. The sampling site is confined to the portion of the drainage area for the Tejalpa and the San Cayetano rivers, natural influents of

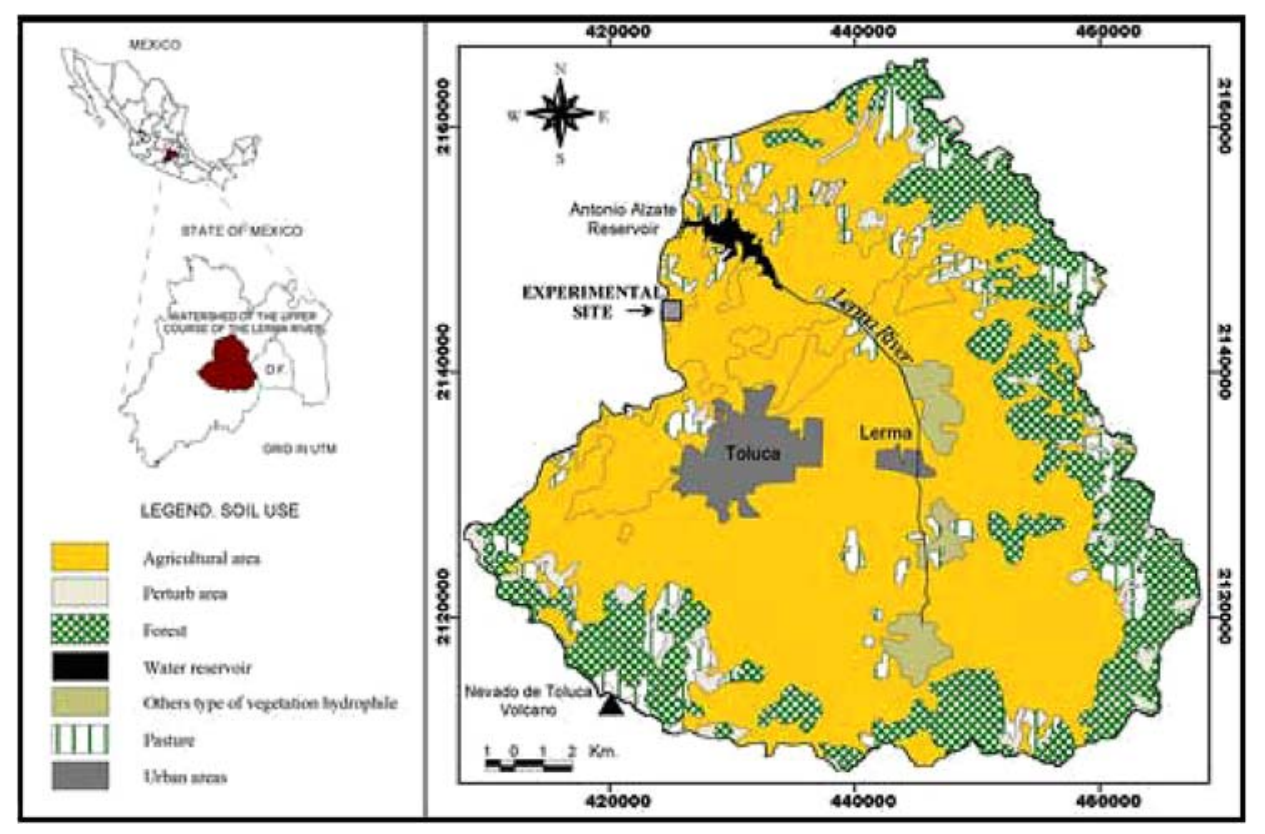

Figure 1. Localization of the Valley of Toluca (Mexico) and map of the area studied. Soil and water sampling sites are indicated with symbols. 
the Lerma river. The average rainfall is about $920 \mathrm{~mm} \mathrm{year}^{-1}$ with a peak in July, and there is a dry season from October to April. The mean annual temperature is $15-18^{\circ} \mathrm{C}$. The topography of the area is that of a flat land and the main crop is corn, which is grown on $90 \%$ of the arable land. This experimental site was selected given its accessibility, its long history of agricultural development, the effective drainage toward the river, and the fact that this site presents the typical crop and soil of the Valley. Agriculture in the Toluca Valley is seasonal, benefiting from the raining period. Sometimes surface water coming from rivers and water reservoirs and groundwater obtained from wells and/or springs are used for irrigation from March to November.

\subsection{ACTIVITIES CARRIED OUT ON THE EXPERIMENTAL SITE}

Local fertilizer is used in three applications: the first is in April, with a content of urea, granulate triple superphosphate (GSP) and potassium chloride in a 65-90-60 formulation $\left(46 \% \mathrm{~N}\right.$ such as urea, $40-52 \% \mathrm{P}_{2} \mathrm{O}_{5}$ such as granular triple superphosphate, and $50-52 \% \mathrm{~K}_{2} \mathrm{O}$ such as potassium chloride, respectively) simultaneously to another 65-00-00 nitrogen fertilizer formulation. The second application is in May and the third one is in June, with the latter formulation. The GSP fertilizer was applied at rates of $198 \mathrm{~kg} \mathrm{ha}^{-1}$, with a dose of $38 \mathrm{~kg}$ of P ha ${ }^{-1}$, and the urea at $141.3 \mathrm{~kg} \mathrm{ha}^{-1}$, with a dose of $65 \mathrm{~kg}$ of $\mathrm{N} \mathrm{ha}^{-1}$. The fertilizers have been applied in this manner for, at least, 20 years. The case of phosphate fertilizer is one of particular interest due to its high $\mathrm{UO}_{2}{ }^{2+}$ concentration, $198 \mathrm{mg} \mathrm{kg}^{-1}$, which represents a $0,03 \mathrm{~kg}$ dose of $\mathrm{UO}_{2}{ }^{2+} \mathrm{ha}^{-1}$. On the other hand, no fertilizer was applied to an uncultivated section of the same plot of land.

\subsection{SOIL AND WATER SAMPLING}

\subsubsection{Soil}

The soil sampling was carried out at two experimental sites (Figure 1). The first one was located in a corn field, and the other in a plot of land that had not been cultivated or fertilized since 1993. Soil samples were collected using an auger spiral at different depths: at 30, 60, 90,120,150 and $180 \mathrm{~cm}$ in the corn field, and 30, 60 and $90 \mathrm{~cm}$ in the not cultivated field.

\subsubsection{Water}

2.3.2.1. Surface water and rain water. A rainwater samples were taken after every intense pluvial precipitation during the agricultural cycle. A water spring, considered the blank test, was located at 3,300 meters above the sea level in a mountainous area $18 \mathrm{~km}$ away from Toluca Valley.

The spring is located in a wooded zone, without the influence of agricultural land. This was our sampling zone closest to the Nevado de Toluca mountain. During the rainy season, surface runoffs and small streams gather in the reservoirs located 
on the high part of the basin. These water bodies were chosen in order to prevent the presence of $\mathrm{N}$ and $\mathrm{P}$ from urban residual water. The influents selected among diverse locations of the Toluca Valley were: Las Minas, Cuatro Arboles and Los Patos (Figure 1).

The Las Minas water body, at a 3,000 $\mathrm{m}$ altitude, is located $14 \mathrm{~km}$ from Toluca city; it is immerse in a zone of moderate agricultural activity with intensive fertilization. The Cuatro Arboles body is 2,800 high and located $12 \mathrm{~km}$ from Toluca city between corn fields with a more intensive agricultural activity than in the previous zone and, therefore, with an even more intensive fertilization. Human settlements exist in the surrounding area. The Los Patos system is $12 \mathrm{~km}$ from Toluca city and $2,800 \mathrm{~m}$ high. This water body is also located between corn fields with intensive fertilization. The water body presents flora and aquatic fauna with some species of wild duck migrating in the summer.

The water from these systems is used for irrigation in the dry season. Water samples were collected in April, July and November, 1997.

2.3.2.2. Soil water. The porous ceramic suction cup samplers employed to collect the soil water in the vadose zone were installed at depths of $15,30,60,90,120,150$ and $180 \mathrm{~cm}$. The collection of soil water was made after applying vacuum to the cup samplers within 3 days of each pluvial precipitation or irrigation. The sampling period for soil water covered 9 months, from June 1997 to March 1998, with six samples, five of them were carried out after intensive rainfall, and the last one after irrigation with groundwater.

2.3.2.3. Groundwater. The groundwater samples were taken in November 1997 and March 1998 from six wells, whose depths vary between 75 and $150 \mathrm{~m}$, that are located within a $5 \mathrm{~km}$ radius around the experimental site (Figure 1). The volume of the groundwater samples was 20 liters.

\subsection{SOIL AND WATER ANALYSES}

\subsubsection{Soil Analysis}

Texture, $\mathrm{pH}$, electrical conductivity and organic matter content of soil samples were determined, Pulido et al. (1992). A mineralogical analysis by X-ray diffraction was also obtained, while the surface area was obtained by the Brunauer-Emmett-Teller (BET) method. The uranium determination by Neutron Activation Analysis was made according to Romero et al. (1995). Phosphate determination was carried out according to Romero et al. (1995) and Pulido et al. (1992), using ammonium phosphomolibdate and tin chloride methods.

\subsubsection{Water Analysis}

Electrical conductivity, temperature, $\mathrm{pH}$ and dissolved oxygen were measured in situ by a Checkmate ${ }^{\circledR}$ portable equipment. Dissolved oxygen was determined only 
in the surface water samples. All water samples for chemical analysis were refrigerated at approximately $4^{\circ} \mathrm{C}$ after their collection. Chemical analysis for determining anions such as bicarbonates-carbonates, chlorides, sulphates, nitrates as well as phosphates, and cations like magnesium, calcium, sodium and potassium can be consulted in the following Standard Methods, American Public Health Association (APHA), American Water Works Association (AWWA) and Water Pollution Control Facility (WPCF) (1995) and in the Norma Oficial Mexicana, DOF (1989). The uranium was determined by a Neutron Activation Analysis technique, as described by Romero et al. (1995). The analytical detection limit for $\mathrm{N}_{-} \mathrm{NO}_{3}$ was $0.44 \mathrm{mg}$ $\mathrm{L}^{-1}$ and for phosphate was $0.1 \mathrm{mg} \mathrm{L}^{-1}$. The analytical detection limit for dissolved $\mathrm{UO}_{2}{ }^{2+}$ was $10^{-9} \mathrm{mgL}^{-1}$.

\subsubsection{Analysis of Data}

Assessing the importance of each one of the physico-chemical soil processes involved during the movement of the water, or attempting their quantification, presents a certain degree of difficulty since many of these processes can interact and produce similar results to those coming from separated reactions. Thus, the application of hydrogeochemical models is valuable for determining the processes present and their reactions. The NETPATH model, Plummer et al. (1991) identified and quantified the mechanisms, along with the ions in the vadose zone.

On the other hand, in order to identify the complexes formed with uranium and phosphate in rainwater, surface water, soil water and groundwater, we used the Make Equilibrium Diagrams Using Sophisticated Algorithms (MEDUSA) program, Puigdomenech (2004). This program allows to determine the existence and prevalence of the main chemical species formed in the water system and to calculate their distribution diagram. One of the advantages of this software over others lies in its modeling feature by which more than three elements can be considered simultaneously, Golberg and Sposito (1984); Kohler et al. (1996).

\section{Results and Discussion}

\subsection{SOIL CHARACTERIZATION}

The physico-chemical characteristics of the soil in the agricultural and non agricultural sites are shown in Tables I and II, respectively.

\subsubsection{Soil Texture}

The textural composition of the soil layers reveals a high content of silt and clays, as well as a low content of sand. However the top layers have a silt-loamy texture; below a depth of $90 \mathrm{~cm}$ and $60 \mathrm{~cm}$, the particle size becomes larger in agricultural and non agricultural sites, respectively. This causes a faster flow of soil water flow to the groundwater. The most abundant minerals identified in both areas are the 
TABLE I

Physico-chemical characteristics of the soil at different depths in the nonagricultural site

\begin{tabular}{llccc}
\hline & & \multicolumn{3}{c}{ Depth } \\
\cline { 3 - 5 } & Unit & $0-30$ & $30-60$ & $60-90$ \\
\hline Clay & $\%$ & $40 \pm 6$ & $58 \pm 3$ & $44 \pm 7$ \\
Silt & $\%$ & $50 \pm 5$ & $37 \pm 2$ & $33 \pm 4$ \\
Sand & $\%$ & $10 \pm 4$ & $5 \pm 2$ & $23 \pm 3$ \\
Surface area & $\mathrm{cm}^{2} \mathrm{~g}^{-1}$ & $18.9 \pm 1.7$ & $48.8 \pm 1.9$ & $28.6 \pm 3.1$ \\
pH & & $5.8 \pm 0.4$ & $6.6 \pm 0.3$ & $7.6 \pm 0.2$ \\
E. C. & $\mu$ Scm $^{-1}$ & $568 \pm 10$ & $127 \pm 31$ & $62 \pm 14$ \\
Organic matter & $\%$ & $5.1 \pm 0.3$ & $4.2 \pm 0.4$ & $3.7 \pm 0.6$ \\
$\mathrm{PO}_{4}{ }^{3-}$ & $\mathrm{mg} \mathrm{kg}$ & $0.37 \pm 0.02$ & $0.14 \pm 0.03$ & $0.06 \pm 0.03$ \\
$\mathrm{UO}_{2}{ }^{2+}$ & $\mathrm{mg} \mathrm{kg}^{-1}$ & $1.03 \pm 0.4$ & $0.5 \pm 0.3$ & $0.4 \pm 0.2$ \\
\hline
\end{tabular}

E.C.: Electrical Conductivity

TABLE II

Physico-chemical characteristics of the soil at different depths in the agricultural site

\begin{tabular}{llcccccc}
\hline & & \multicolumn{7}{c}{ Depth } \\
\cline { 2 - 7 } & Unit & $0-30$ & $30-60$ & $60-90$ & $90-120$ & $120-150$ & $150-180$ \\
\hline \% Clay & $\%$ & $42 \pm 4$ & $52 \pm 2$ & $62 \pm 5$ & $48 \pm 3$ & $45 \pm 7$ & $48 \pm 4$ \\
\% Silt & $\%$ & $51 \pm 5$ & $43 \pm 6$ & $36 \pm 3$ & $30 \pm 8$ & $35 \pm 4$ & $47 \pm 6$ \\
\% Sand & $\%$ & $7 \pm 4$ & $5 \pm 2$ & $2 \pm 6$ & $22 \pm 3$ & $20 \pm 6$ & $5 \pm 2$ \\
Surface area & $\mathrm{cm}^{2} \mathrm{~g}^{-1}$ & $19.3 \pm 3.7$ & $20.3 \pm 2.3$ & $53.3 \pm 1.6$ & $44.7 \pm 2.1$ & $30.6 \pm 2.4$ & $45.0 \pm 1.7$ \\
pH & & $6.2 \pm 0.1$ & $6.4 \pm 0.4$ & $6.5 \pm 0.6$ & $7.3 \pm 0.1$ & $6.9 \pm 0.1$ & $6.7 \pm 0.3$ \\
E. C. & $\mu \mathrm{Scm}^{-1}$ & $62 \pm 14$ & $68 \pm 17$ & $97 \pm 11$ & $155 \pm 20$ & $111 \pm 25$ & $95 \pm 30$ \\
Organic matter & $\%$ & $0.9 \pm 0.4$ & $1.7 \pm 0.7$ & $0.5 \pm 0.1$ & $0.3 \pm 0.2$ & $0.2 \pm 0.3$ & $0.3 \pm 0.2$ \\
$\mathrm{PO}_{4}{ }^{3-}$ & $\mathrm{mg} \mathrm{kg}^{-1}$ & $30.2 \pm 4.5$ & $22.5 \pm 3.8$ & $37.4 \pm 5.3$ & $28.0 \pm 4.5$ & $22.7 \pm 2.9$ & $24.0 \pm 5.1$ \\
$\mathrm{UO}_{2}{ }^{2+}$ & $\mathrm{mg} \mathrm{kg}^{-1}$ & $31.2 \pm 5.9$ & $50.6 \pm 4.7$ & $37.0 \pm 3.3$ & $28.1 \pm 4.0$ & $15.6 \pm 3.6$ & $19.5 \pm 2.4$ \\
\hline $\mathrm{EC}^{2}$ & & & & & & & \\
\hline
\end{tabular}

E.C.: Electrical Conductivity

albite, $\mathrm{NaAlSi}_{3} \mathrm{O}_{8}$, and the anorthite, $\mathrm{CaAl}_{2} \mathrm{Si}_{2} \mathrm{O}_{8}$, (Joint Committee on Powder Diffraction Standards (JCPDS) cards 10-0393 and 20-0528, respectively; Bayliss et al. (1986). The albite and anorthite are plagioclases that form an isomorphic series which varies from pure sodic pheldesphate to pure calcic pheldesphate. The most abundant chemical elements are oxygen, silica, carbon, aluminum, sodium and calcium (Table III).

\subsubsection{Surface Area}

The surface area analysis revealed that the $60-90 \mathrm{~cm}$ layer of soil from the agricultural site and the $30-60 \mathrm{~cm}$ layer from the non agricultural site presented the largest porous area $\left(53.3 \mathrm{~cm}^{2} \mathrm{~g}^{-1}\right.$ and $\left.48.8 \mathrm{~cm}^{2} \mathrm{~g}^{-1}\right)$, with the highest water volume, as its textural classification had been indicated. 
TABLE III

Elemental microanalysis of soil samples collected at a $60-90 \mathrm{~cm}$ depth

\begin{tabular}{lcc}
\hline Element & \% weight & \% atomic \\
\hline $\mathrm{O}_{2}$ & 42.36 & 49.79 \\
$\mathrm{Si}$ & 23.54 & 15.76 \\
$\mathrm{C}$ & 13.16 & 20.61 \\
$\mathrm{Al}$ & 11.60 & 8.08 \\
$\mathrm{Na}$ & 4.21 & 3.44 \\
$\mathrm{Ca}$ & 3.17 & 1.49 \\
$\mathrm{Fe}$ & 1.34 & 0.45 \\
$\mathrm{~K}$ & 0.33 & 0.16 \\
$\mathrm{Mg}$ & 0.30 & 0.23 \\
Total & 100 & 100 \\
\hline
\end{tabular}

\subsubsection{PH Values and Organic Matter}

The $\mathrm{pH}$ value in both areas was found between 5.8 and 7.6. This $\mathrm{pH}$ range is the most favorable condition for the formation of the main uranyl phosphate complexes. Moreover, these $\mathrm{pH}$ values make nutrients such as phosphate and nitrates more readily available to plants. In both areas, the organic matter content ranges from 0.2 to $5.1 \%$.

\subsubsection{Phosphate and Uranium Distribution}

The phosphate concentration in the agricultural area is from 22.5 to $37.4 \mathrm{mg} \cdot \mathrm{kg}^{-1}$, distributed randomly through the soil profile, while in the nonagricultural area it ranges from 0.06 to $0.37 \mathrm{mg} \cdot \mathrm{kg}^{-1}$ although the phosphate concentration decreased with depth in both areas (Figure 2).

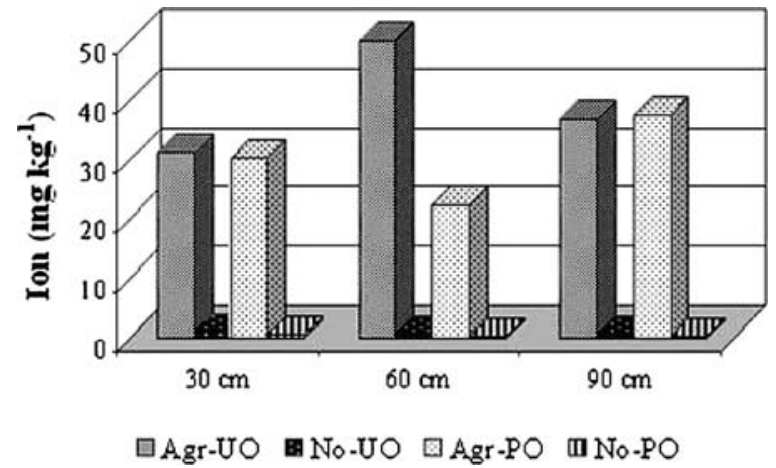

Figure 2. $\mathrm{PO}_{4}{ }^{3-}$ and $\mathrm{UO}_{2}{ }^{2+}$ concentrations at various soil depths for agricultural and nonagricultural sites. 


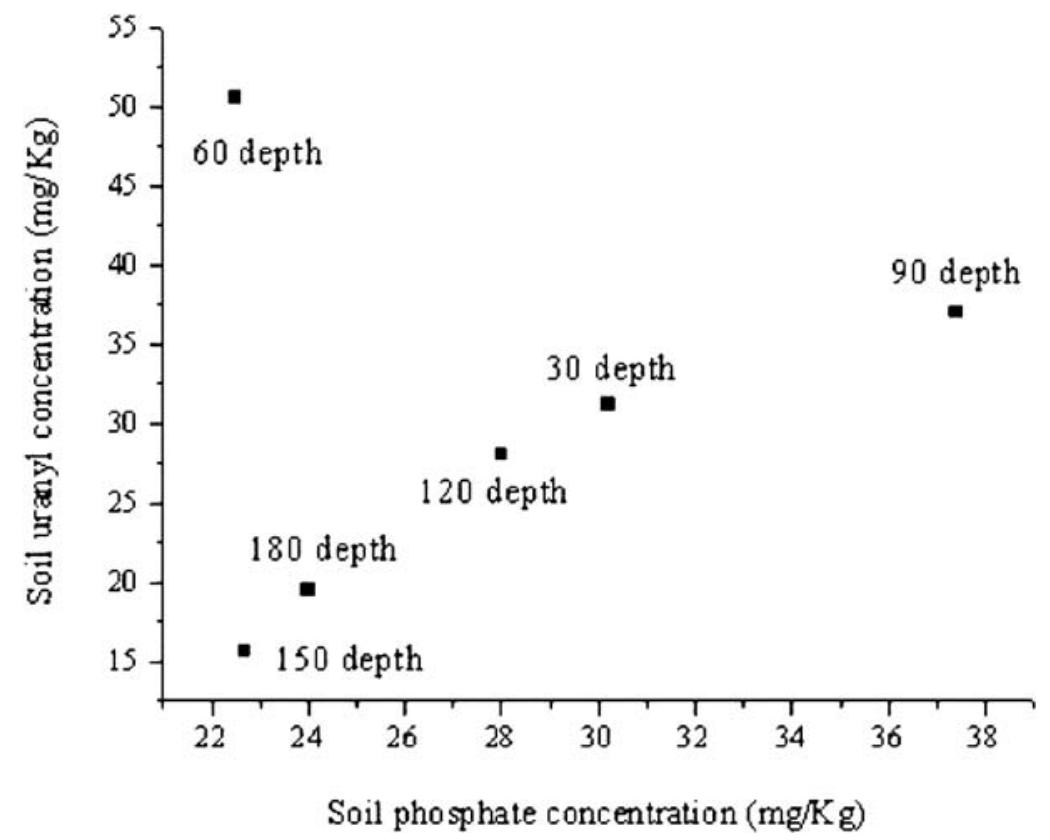

Figure 3. Relation between soil phosphate concentration and soil uranyl concentration in the agricultural site.

It is important to point out that the occurrence of phosphate is approximately 100 times greater in the agricultural area than in the non agricultural area, because the intensive phosphate fertilization is applied without technical advice (Figure 2).

The uranium concentrations in agricultural area oscillate between 50.6, and $19.5 \mathrm{mg} \cdot \mathrm{kg}^{-1}$, values that exceeds the permissible limit of $2.1 \mathrm{mg} \cdot \mathrm{kg}^{-1}$, Linsalata (1989). In the nonagricultural area, the uranium concentration remained low, between 0.4 and $1.0 \mathrm{mg} \cdot \mathrm{kg}^{-1}$; decreasing with depth (Figure 2).

It is noticeable that the higher uranium concentration was found at $60 \mathrm{~cm}$ deep with very low phosphate content, that suggest that the mineral nature of this layer play an important roll in uranium retention (Figure 3).

\subsection{WATER CHARACTERIZATION}

\subsubsection{Surface Water and Rain Water}

The results of the physico-chemical analysis of the surface water and rain water have been summarized in Table IV. These data represent mean values (and standard derivation) during the sampling period. Measures of $\mathrm{pH}$ in the surface water indicate a small variation at each sampling site. The electrical conductivity increased downstream from 157 to $414 \mu \mathrm{Scm}^{-1}$ and the temperature increased from 17.8 to $21.9^{\circ} \mathrm{C}$. The dissolved oxygen concentration varied between 2.6 and $3.7 \mathrm{mgL}^{-1}$. 
TABLE IV

Physico-chemical characteristics of the surface and rain water samples (values in $\mathrm{mg} \mathrm{L}^{-1}$ except $\mathrm{UO}_{2}{ }^{2+}$ in $\mu \mathrm{g} \mathrm{L}^{-1}$ and electrical conductivity in $\mu \mathrm{S} \mathrm{cm}^{-1}$ )

\begin{tabular}{lcccc}
\hline & Minas & Árboles & Patos & Rain water \\
\hline $\mathrm{T}\left({ }^{\circ} \mathrm{C}\right)$ & $17.8 \pm 0.9$ & $19.9 \pm 1.8$ & $21.9 \pm 2.9$ & $15.9 \pm 1.5$ \\
$\mathrm{pH}$ & $7.53 \pm 0.5$ & $7.45 \pm 0.6$ & $7.33 \pm 0.3$ & $7.4 \pm 0.5$ \\
E.C. & $157 \pm 53$ & $313 \pm 80$ & $414 \pm 14$ & $211 \pm 69$ \\
D.O. & $3.74 \pm 0.71$ & $2.68 \pm 0.53$ & $3.68 \pm 0.59$ & $88 \pm 3$ \\
$\mathrm{HCO}_{3}{ }^{-}$ & $48 \pm 9$ & $171 \pm 87$ & $179 \pm 20$ & $1.9 \pm 1.1$ \\
$\mathrm{SO}_{4}{ }^{2-}$ & $22.6 \pm 25.1$ & $27.0 \pm 19.8$ & $99.3 \pm 49.6$ & $3.8 \pm 1.2$ \\
$\mathrm{Cl}^{-}$ & $3.1 \pm 2.3$ & $12.5 \pm 3.3$ & $14.8 \pm 4.1$ & $1.2 \pm 0.5$ \\
${\mathrm{~N}-\mathrm{NO}_{3}{ }^{-}}_{\mathrm{PO}_{4}{ }^{3-}}^{1.2 \pm 2.4}$ & $1.9 \pm 4.9$ & $1.6 \pm 1.7$ & $0.3 \pm 0.5$ \\
$\mathrm{Ca}^{2+}$ & $0.3 \pm 0.4$ & $2.3 \pm 2.5$ & $0.4 \pm 0.4$ & $4.6 \pm 3.5$ \\
$\mathrm{Mg}^{2+}$ & $5.5 \pm 6.9$ & $8.4 \pm 4.7$ & $24.3 \pm 14.3$ & $10.5 \pm 6.6$ \\
$\mathrm{Na}^{+}$ & $9.5 \pm 5.9$ & $13.0 \pm 2.4$ & $25.8 \pm 5.2$ & $4.6 \pm 0.1$ \\
$\mathrm{~K}^{+}$ & $4.3 \pm 0.7$ & $11.1 \pm 5.8$ & $12.2 \pm 11.3$ & $1.8 \pm 0.4$ \\
$\mathrm{UO}_{2}{ }^{2+}$ & $2.7 \pm 0.7$ & $9.2 \pm 3.3$ & $19.5 \pm 27.9$ & $0.24 \pm 0.11$ \\
\hline
\end{tabular}

E.C.: Electrical Conductivity; D.O.: Dissolved oxygen; N.D: Not detected

The concentration ranges of inorganic anions in surface waters were variable. The main anions and cations were $\mathrm{HCO}_{3}{ }^{-}$and $\mathrm{Mg}^{2+}$, respectively. The rain water presented minimal ion concentration and low electrical conductivity values.

\subsubsection{Soil Water}

The physico-chemical characteristics of soil water collected at different depths are shown in Table V. These data also represent mean values and standard derivation. The sample temperature range was around $18^{\circ} \mathrm{C}$, the soil water $\mathrm{pH}$ ranged between 6.69 and 7.24, and the electrical conductivity generally ranged from 450 to $784 \mu \mathrm{Scm}^{-1}$, with the maximum value at a depth of $60 \mathrm{~cm}$. All soil water samples revealed similar ionic dominance: mainly $\mathrm{Ca}^{2+}$ and $\mathrm{HCO}_{3}^{-}$, however there are some samples $(15,90$ and $150 \mathrm{~cm})$ with high concentration of $\mathrm{SO}_{4}^{2-}$. This fact suggests some leaching of ammonium sulfate fertilizers, which are applied also in the highland.

\subsubsection{Groundwater}

The characteristics of groundwater are listed in Table VI as mean values and standard derivation. The temperature normally ranged from 13.5 to $19.3^{\circ} \mathrm{C}$. These values reflect the average annual air temperature, with a possible additional geothermal component. Water in the aquifer is fresh, with an electric conductivity range from 211 to $482 \mu \mathrm{Scm}^{-1}$.

The results of major ion concentrations in the water samples (soil water, groundwater, suface water and rain water) were plotted in a Piper Diagram (Figure 4). They suggest that the groundwater in the Toluca Valley aquifer has a water type 
TABLE V

Physico-chemical characteristics of soil water samples (values in $\mathrm{mgL}^{-1}$ and electrical conductivity in $\mu \mathrm{S} \mathrm{cm}^{-1}$ )

\begin{tabular}{lccccccc}
\hline Depth & $15 \mathrm{~cm}$ & $30 \mathrm{~cm}$ & $60 \mathrm{~cm}$ & $90 \mathrm{~cm}$ & $120 \mathrm{~cm}$ & $150 \mathrm{~cm}$ & $180 \mathrm{~cm}$ \\
\hline $\mathrm{T}\left({ }^{\circ} \mathrm{C}\right)$ & $18.8 \pm 4.1$ & $18.7 \pm 2.9$ & $18.8 \pm 3.6$ & $18.8 \pm 2.9$ & $18.3 \pm 2.7$ & $18.3 \pm 2.6$ & $18.1 \pm 2.5$ \\
$\mathrm{PH}$ & $7.24 \pm 0.5$ & $7.10 \pm 0.5$ & $7.08 \pm 0.5$ & $6.98 \pm 0.5$ & $6.97 \pm 0.5$ & $6.69 \pm 0.4$ & $7.20 \pm 0.4$ \\
E.C. & $523 \pm 130$ & $553 \pm 141$ & $785 \pm 225$ & $511 \pm 45$ & $540 \pm 60$ & $450 \pm 64$ & $508 \pm 125$ \\
$\mathrm{HCO}_{3}{ }^{-}$ & $127 \pm 78$ & $126 \pm 49$ & $201 \pm 66$ & $91 \pm 17$ & $91 \pm 24$ & $69.7 \pm 22.2$ & $135.2 \pm 8.5$ \\
$\mathrm{SO}_{4}{ }^{2-}$ & $184.4 \pm 21.6$ & $63.4 \pm 29.0$ & $50.6 \pm 52.3$ & $104.4 \pm 55.9$ & $53.0 \pm 49.8$ & $87.1 \pm 51.1$ & $77.3 \pm 73.7$ \\
$\mathrm{Cl}^{-}$ & $9.1 \pm 2.1$ & $16.6 \pm 5.4$ & $19.3 \pm 12.2$ & $14.8 \pm 6.5$ & $14.0 \pm 7.2$ & $13.3 \pm 5.5$ & $16.7 \pm 1.8$ \\
${\mathrm{~N}-\mathrm{NO}_{3}^{-}}^{1.7} \pm 2.2$ & $1.9 \pm 1.7$ & $0.8 \pm 1.6$ & $2.4 \pm 2.8$ & $1.8 \pm 8.1$ & $5.5 \pm 9.3$ & $0.8 \pm 1.5$ \\
$\mathrm{PO}_{4}{ }^{3-}$ & $0.50 \pm 0.21$ & $0.46 \pm 0.14$ & $0.93 \pm 0.13$ & $0.50 \pm 0.10$ & $0.46 \pm 0.11$ & $0.93 \pm 0.21$ & $0.51 \pm 0.40$ \\
$\mathrm{Ca}^{2+}$ & $28.6 \pm 18.1$ & $35.2 \pm 10.8$ & $43.1 \pm 11.9$ & $30.2 \pm 6.7$ & $29.6 \pm 4.8$ & $21.2 \pm 11.1$ & $26.3 \pm 12.5$ \\
$\mathrm{Mg}^{2+}$ & $16.4 \pm 8.9$ & $16.9 \pm 7.4$ & $28.5 \pm 8.2$ & $18.8 \pm 4.6$ & $16.8 \pm 6.7$ & $12.9 \pm 4.7$ & $18.6 \pm 6.1$ \\
$\mathrm{Na}^{+}$ & $12.9 \pm 9.4$ & $20.8 \pm 24.1$ & $14.4 \pm 3.3$ & $21.0 \pm 11.3$ & $19.3 \pm 10.7$ & $18.0 \pm 11.4$ & $12.8 \pm 12.1$ \\
$\mathrm{~K}^{+}$ & $3.2 \pm 3.3$ & $4.0 \pm 2.7$ & $2.9 \pm 8.2$ & $1.1 \pm 1.4$ & $1.7 \pm 2.3$ & $1.7 \pm 2.7$ & $2.6 \pm 0.9$ \\
$\mathrm{UO}_{2}{ }^{2+}$ & $3.9 \pm 2.3$ & $4.5 \pm 4.0$ & $10.3 \pm 8.9$ & $3.7 \pm 3.5$ & $4.2 \pm 4.4$ & $5.9 \pm 6.9$ & $2.5 \pm 1.9$ \\
\hline
\end{tabular}

E.C.: Electrical Conductivity

TABLE VI

Physico-chemical characteristics of groundwater samples (values in $\mathrm{mgL}^{-1}$ except $\mathrm{UO}_{2}{ }^{2+}$ in $\mu \mathrm{g} \mathrm{L}^{-1}$ and electrical conductivity in $\mu \mathrm{S} \mathrm{cm}^{-1}$ )

\begin{tabular}{lccccccc}
\hline & Well 1 & Well 2 & Well 3 & Well 4 & Well 5 & Well 6 & Spring \\
\hline $\mathrm{T}\left({ }^{\circ} \mathrm{C}\right)$ & $19.3 \pm 2.3$ & $15.1 \pm 4.8$ & $13.5 \pm 3.7$ & $17.7 \pm 0.8$ & $16.6 \pm 1.5$ & $15.4 \pm 1.4$ & $15.9 \pm 1.5$ \\
$\mathrm{PH}$ & $6.8 \pm 0.3$ & $6.6 \pm 0.6$ & $6.7 \pm 0.4$ & $6.4 \pm 0.3$ & $6.5 \pm 0.6$ & $6.3 \pm 0.2$ & $7.4 \pm 0.5$ \\
$\mathrm{E} . \mathrm{C}$. & $482 \pm 41$ & $460 \pm 22$ & $418 \pm 31$ & $471 \pm 56$ & $384 \pm 59$ & $239 \pm 15$ & $210 \pm 69$ \\
$\mathrm{HCO}_{3}{ }^{-}$ & $134 \pm 3$ & $179 \pm 62$ & $196 \pm 43$ & $191 \pm 71$ & $185 \pm 68$ & $93 \pm 1$ & $88 \pm 3$ \\
$\mathrm{SO}_{4}{ }^{2-}$ & $13.8 \pm 5.5$ & $6.3 \pm 0.1$ & $8.5 \pm 2.2$ & $7.3 \pm 0.3$ & $5.2 \pm 0.8$ & $4.1 \pm 0.3$ & $1.9 \pm 1.1$ \\
$\mathrm{Cl}^{-}$ & $3.1 \pm 0.2$ & $6.8 \pm 3.5$ & $3.3 \pm 0.6$ & $6.2 \pm 1.7$ & $4.2 \pm 3.3$ & $3.7 \pm 0.9$ & $3.1 \pm 2.1$ \\
${\mathrm{~N}-\mathrm{NO}_{3}}^{-}$ & $7.9 \pm 0.2$ & $4.4 \pm 0.3$ & $1.4 \pm 0.3$ & $2.2 \pm 0.1$ & $3.9 \pm 0.1$ & $2.4 \pm 0.1$ & $1.2 \pm 0.5$ \\
$\mathrm{PO}_{4}{ }^{3-}$ & $0.3 \pm 0.2$ & $0.6 \pm 0.3$ & $0.3 \pm 0.3$ & $0.6 \pm 0.5$ & $0.5 \pm 0.2$ & $0.9 \pm 0.9$ & $0.3 \pm 0.5$ \\
$\mathrm{Ca}^{2+}$ & $28.7 \pm 1.8$ & $32.2 \pm 1.9$ & $28.6 \pm 1.3$ & $29.7 \pm 2.3$ & $23.1 \pm 1.1$ & $19.2 \pm 0.6$ & $4.7 \pm 3.5$ \\
$\mathrm{Mg}^{2+}$ & $12.9 \pm 1.7$ & $17.9 \pm 4.7$ & $12.4 \pm 4.2$ & $14.4 \pm 3.1$ & $13.7 \pm 3.4$ & $14.2 \pm 1.1$ & $10.5 \pm 6.9$ \\
$\mathrm{Na}^{+}$ & $36.9 \pm 3.9$ & $32.2 \pm 2.7$ & $31.1 \pm 2.0$ & $25.4 \pm 9.5$ & $26.2 \pm 2.3$ & $27.0 \pm 0.9$ & $15.9 \pm 1.5$ \\
$\mathrm{~K}^{+}$ & $18.4 \pm 8.8$ & $12.6 \pm 2.1$ & $10.8 \pm 0.5$ & $15.6 \pm 4.1$ & $11.1 \pm 3.1$ & $10.6 \pm 2.1$ & $1.8 \pm 0.4$ \\
$\mathrm{UO}_{2}{ }^{2+}$ & $0.61 \pm 0.04$ & $0.66 \pm 0.03$ & $0.88 \pm 0.03$ & $0.40 \pm 0.20$ & $0.28 \pm 0.01$ & $0.26 \pm 0.17$ & $0.24 \pm 0.11$ \\
\hline
\end{tabular}

E.C.: Electrical Conductivity

composition $\mathrm{Ca}^{2+}-\mathrm{Na}^{+}-\mathrm{HCO}_{3}{ }^{2-}$. This type of composition is typical of volcanic aquifers: feldspars contribute sodium, calcium and potassium, and the pyroxenes and biotites contribute calcium, and magnesium. The abundance of sulphates and chlorides is low, due to the fact that volcanic rocks contain such ions in small amounts, Esteller and Andreu, 2005.

The soil water has an intermediate water type composition between $\mathrm{Ca}^{2+}-\mathrm{Mg}^{2+}$ $\mathrm{HCO}_{3}{ }^{2-}$ and $\mathrm{Mg}^{2+}-\mathrm{Ca}^{2+}-\mathrm{SO}_{4}{ }^{2-}$ waters. The rain water is basically a sulphate 


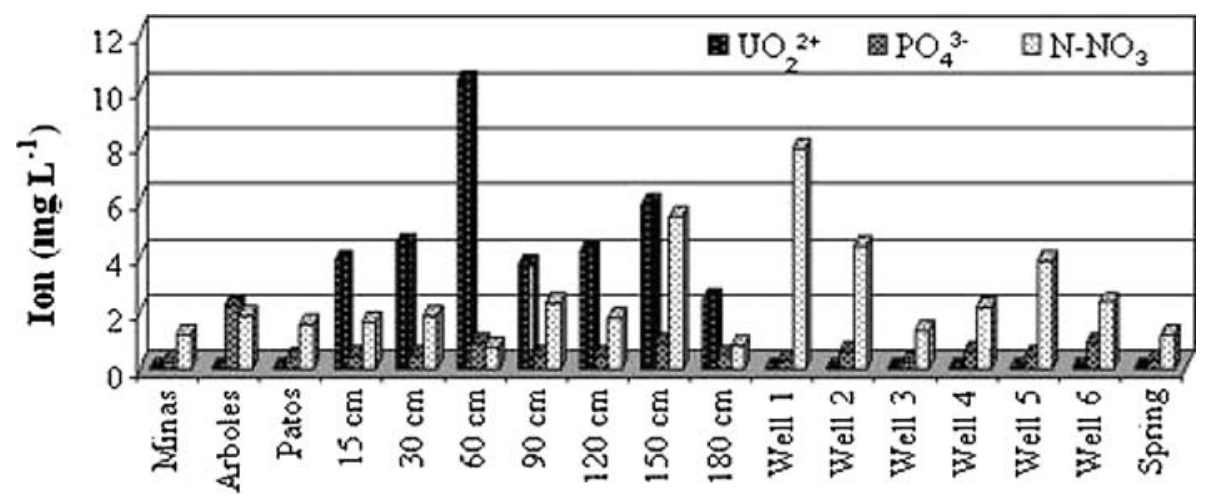

Figure 4. $\mathrm{PO}_{4}{ }^{3-}, \mathrm{UO}_{2}{ }^{2+}$ and $\mathrm{N}-\mathrm{NO}_{3}{ }^{-}$concentrations in surface water, soil water and groundwater (average values).

water, with $\mathrm{Ca}^{2+}$ being the prevailing cation whereas the surface water is a bicarbonate water, with $\mathrm{Ca}^{2+}$ being the prevailing cation.

The behaviour of the main water ions analyzed in this work, i.e., uranyl, phosphates and nitrates, is shown in Figure 5. The highest concentration of uranium was found in soil water and the lowest appeared in surface and groundwater. The uranium concentration diminishes from $10 \mathrm{mgL}^{-1}$ in the soil water to $0.3 \mathrm{mgL}^{-1}$ in the groundwater. As for phosphates, similar concentrations were observed in all water types (from 0.3 to $0.9 \mathrm{mgL}^{-1}$ ). The data obtained allowed us to verify that approximately $90 \%$ of phosphate is retained in the soil and only a small portion can migrate through the vadose zone. It is pertinent to point out that the phosphate concentration in the surface water is low $\left(0.3-2.3 \mathrm{mgL}^{-1}\right)$, yet in the sampling carried out after the fertilizer application, the phosphate content increased considerably $\left(8.5 \mathrm{mgL}^{-1}\right)$, in comparison with the rest of the values found. The concentration of phosphates and uranium found in the groundwater is considered into the permitted intervals (uranium $0.001-0.01 \mathrm{mgL}^{-1}$ and phosphates $0.01-1 \mathrm{mgL}^{-1}$ ). These values were not different from the phosphate and uranium concentrations detected in the spring.

In soil water, the uranium and phosphate concentration generally decreased with depth. For uranium as well as for phosphate, a maximum was detected at $60 \mathrm{~cm}$ deep. This maximum was related to the presence of clay minerals, whose large surface area facilitates the interaction between particles and water, favoring reaction mechanisms such as precipitation, dissolution, ionic exchange, sorption, etc.

The dissolved $\mathrm{N}-\mathrm{NO}_{3}$ concentrations in the water samples were variable. In the surface waters, the $\mathrm{N}^{-\mathrm{NO}_{3}}$ concentration was barely detectable $\left(1.2-1.9 \mathrm{mgL}^{-1}\right)$, but, in the sampling after fertilizer application, $13 \mathrm{mg} \mathrm{L}^{-1}$ were detected. The $\mathrm{N}-\mathrm{NO}_{3}$ concentration in the groundwater ranged from 1.2 to $7.9 \mathrm{mgL}^{-1}$. A few 


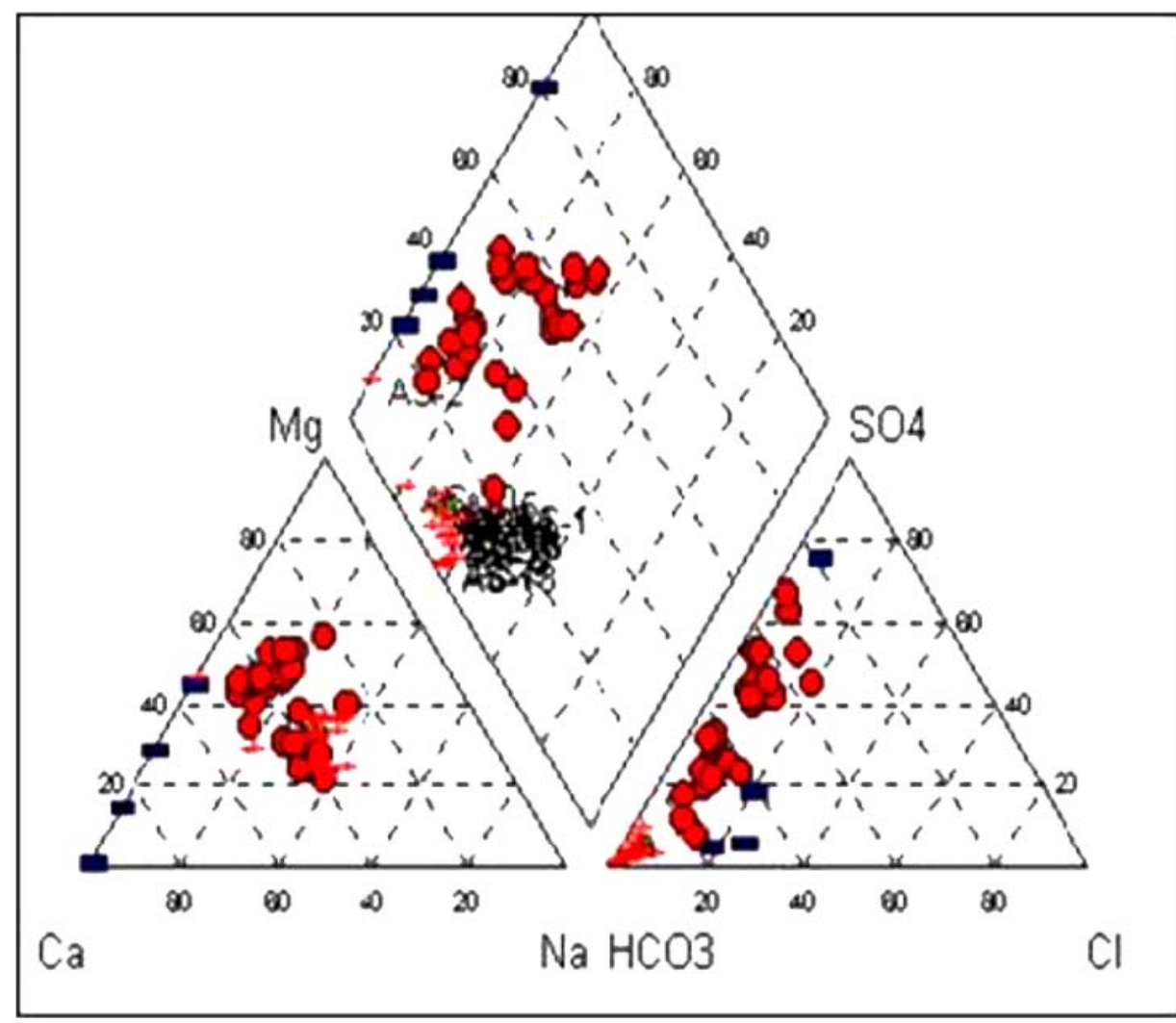

\section{Soil water $\square$ Rainxatex + Groundwater}

Figure 5. Piper diagram of hydrochemical data in the Toluca Valley aquifer.

concentrations values exceeded the $3 \mathrm{mgL}^{-1}$ value suggested for natural source of $\mathrm{N}-\mathrm{NO}_{3}$ in groundwater, Custodio and Llamas (1983). In contrast, the soil water revealed $\mathrm{N}-\mathrm{NO}_{3}$ concentrations, generally in the range from 0.8 to $8.0 \mathrm{mgL}^{-1}$. In all cases, the $\mathrm{N}-\mathrm{NO}_{3}$ concentrations in waters were within the acceptable limits for drinking water $\left(10 \mathrm{mgL}^{-1} \mathrm{~N}-\mathrm{NO}_{3}\right)$. The nitrate mobility through the vadose zone was very similar in all sampling surveys, except at the first and last sampling. In the first case, a high nitrate concentration was detected in the top layers as a result of the recent application and solubilization of nitrogened fertilizers. Likewise in the last campaign, a high nitrate concentration was detected in the deep layers as a consequence of the solubilization and leaching of nitrate ions. The nitrate behavior suggests that a high percentage of these ions is leached through the vadose zone until they reach the groundwater, while a very low percentage of them merge into the superficial waters. 
From the facts described above, the uranium, phosphate and nitrate ions in the soil water seem to be related to the phosphate and nitrogened fertilizers applied in the soil, because neither the rainwater, the surface water nor the groundwater presented high concentrations of these ions.

\subsection{Chemistry MOdeling}

In order to study the behavior of the uranium in the water, chemical speciation models were applied to determine the main species as well as their existence and predominance in the water system. A thermodynamic speciation calculation was made with the MEDUSA software. The calculated value for the ionic strength of each water sample, together with the data of concentration, for each component, uranyl, phosphate or nitrate, were introduced in the MEDUSA software so to obtain the predominance diagrams for each depth and identify the predominant specie. The ionic strength (I) was defined as one half of the total sum of the concentration $\left(\mathrm{c}_{i}\right)$ of every ionic species (i) in the solution times the square of its charge $\left(\mathrm{z}_{i}\right)$, namely, $I=0.5 \Sigma\left(\mathrm{c}_{i} \mathrm{z}_{i}^{2}\right)$.

\subsubsection{Surface Water}

The predominance diagram of the uranyl formed species is presented in Figure 6. The species are regulated by the carbonate system. In this figure, the main species

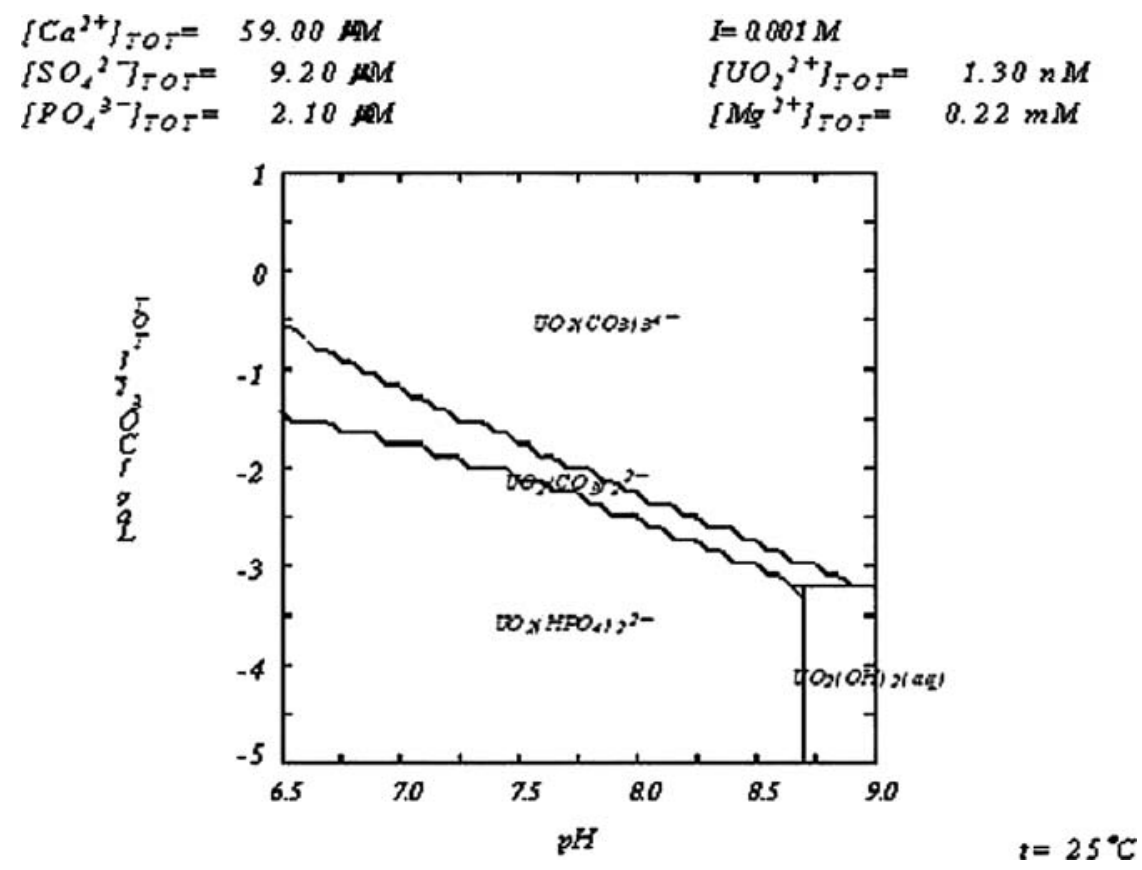

Figure 6. Predominance diagram of uranyl species found in surface water at La Presa. 


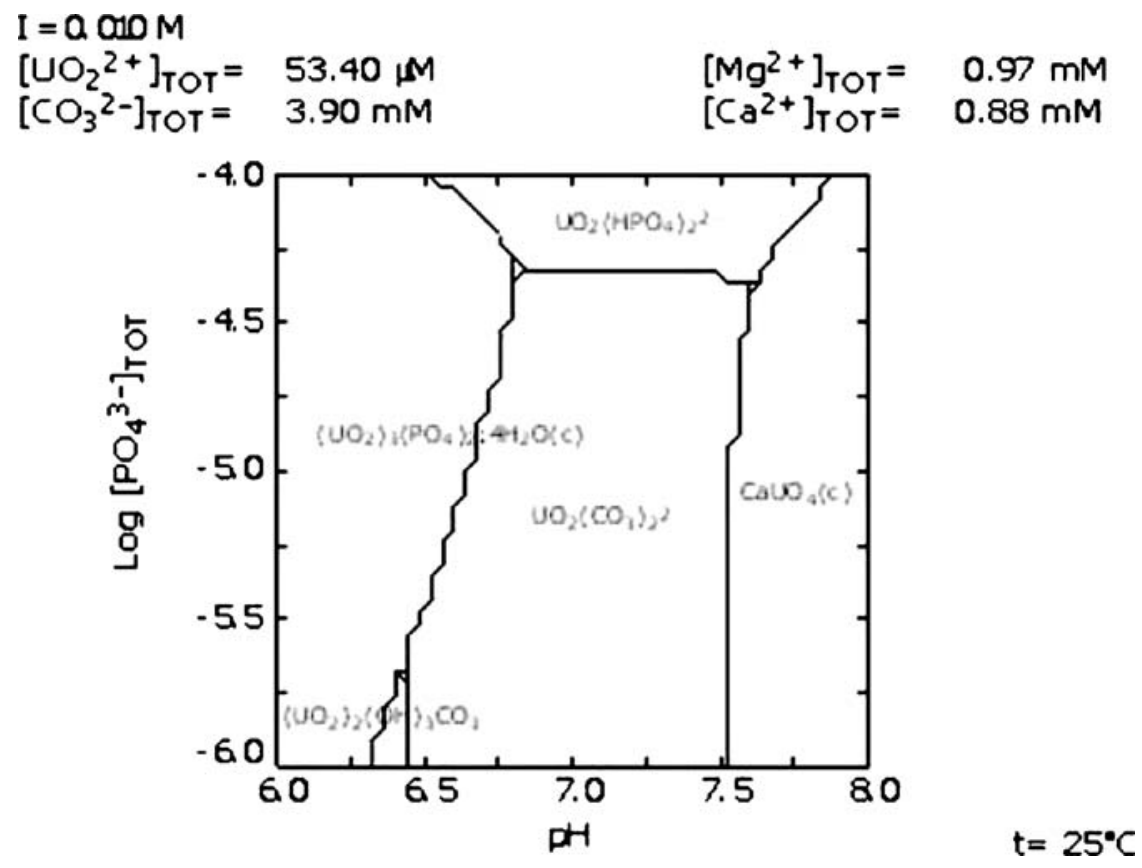

Figure 7. Predominance diagram of uranyl species found in soil water.

shown in accordance with the $\mathrm{pH}$ that prevailed (6.5-9.0) are $\mathrm{UO}_{2}\left(\mathrm{HPO}_{4}\right)_{2}{ }^{2-}$ and $\mathrm{UO}_{2}\left(\mathrm{CO}_{3}\right)_{2}{ }^{2-}$ and in a low carbonate concentration $\left(3.2 \times 10^{-3} \mathrm{M}\right)$ the main species is $\mathrm{UO}_{2}\left(\mathrm{CO}_{3}\right)_{2}{ }^{2-}$.

\subsubsection{Soil Water}

The predominance diagram of the uranyl formed species is presented in Figure 7. The species are regulated by the carbonate system. In this figure, the main species shown in accordance with the $\mathrm{pH}$ that prevailed (6.0-8.0) is $\mathrm{UO}_{2}\left(\mathrm{CO}_{3}\right)_{2}{ }^{2-}$ and in a low carbonate concentration, the main species are $\left(\mathrm{UO}_{2}\right)_{3}\left(\mathrm{PO}_{4}\right)_{2} \cdot 4 \mathrm{H}_{2} \mathrm{O}_{(c)}$ and $\mathrm{CaUO}_{4(\mathrm{c})}$, which are highly stable species. Inversely, with a higher carbonate concentration, $\mathrm{UO}_{2}\left(\mathrm{CO}_{3}\right)_{3}{ }^{4-}$ specie is formed which is the most stable species in the soil water. When the carbonate concentration is almost null, the formation of $\mathrm{UO}_{2}(\mathrm{OH})_{2} \cdot \mathrm{H}_{2} \mathrm{O}$ takes place. Thus, it is evident that both the alkalinity and the $\mathrm{pH}$ have an important effect on the uranium concentration in the water.

In Figure 7, the predominance diagram of uranyl phosphate species is presented; one can see that several species exist in the system, within the 6.0 to 8.0 $\mathrm{pH}$ interval. The soluble species formed are $\mathrm{UO}_{2}\left(\mathrm{HPO}_{4}\right)_{2}{ }^{2-}, \mathrm{UO}_{2}\left(\mathrm{CO}_{3}\right)_{2}{ }^{2-}$ and $\left(\mathrm{UO}_{2}\right)_{2}(\mathrm{OH})_{3} \mathrm{CO}_{3}{ }^{-}$; while two species that precipitate are $\left(\mathrm{UO}_{2}\right)_{3}\left(\mathrm{PO}_{4}\right)_{2} \cdot 4 \mathrm{H}_{2} \mathrm{O}_{(c)}$ and $\mathrm{CaUO}_{4(\mathrm{c})}$. 


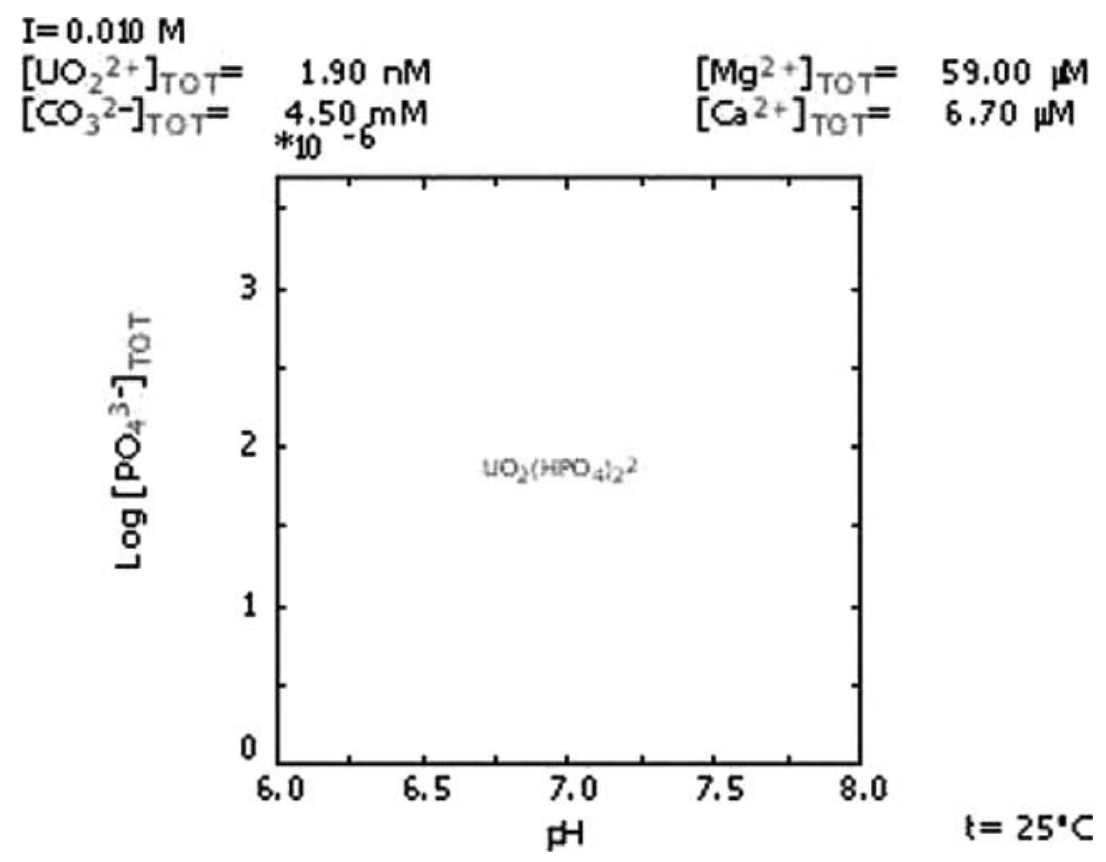

Figure 8. Predominance diagram of uranyl species found in groundwater.

\subsubsection{Groundwater}

Uranyl phosphate, $\mathrm{UO}_{2}\left(\mathrm{HPO}_{4}\right)_{2}{ }^{2-}$ (Drever, 1988; Fetter, 1993; Deutsh, 1997; Domenico y Schuwartz, 1998), is the only species formed in the aqueous system, within the 6 to $8 \mathrm{pH}$ range and in the phosphate concentrations found (Figure 8). The constant formation of phosphate species seems to be responsible for this, due to its stability, although the concentration is low.

The chemical speciation diagrams show that the main factors that control the migration of phosphates and uranium through the vadose zone are the $\mathrm{pH}$ and phosphate, bicarbonate and uranyl concentrations. Besides, it is important to point out that the involved processes are not separated and that they occur in vadose zone.

\subsection{URANIUM, PHOSPHATE AND NITROGEN BEHAVIOR IN THE VADOSE ZONE}

\subsubsection{Uranium}

The behavior of the uranium distribution through the vadose zone was evaluated using a normal statistical Kriging method, Journel, 1989. The vertical distribution of uranium was observed from July 1997 to March 1998, during six sampling campaigns. Each diagram shows the movement of uranium in one sampling at 15, $30,60,90,120,150$ and $180 \mathrm{~cm}$ in two series of samplers. On July 23/1997, the 

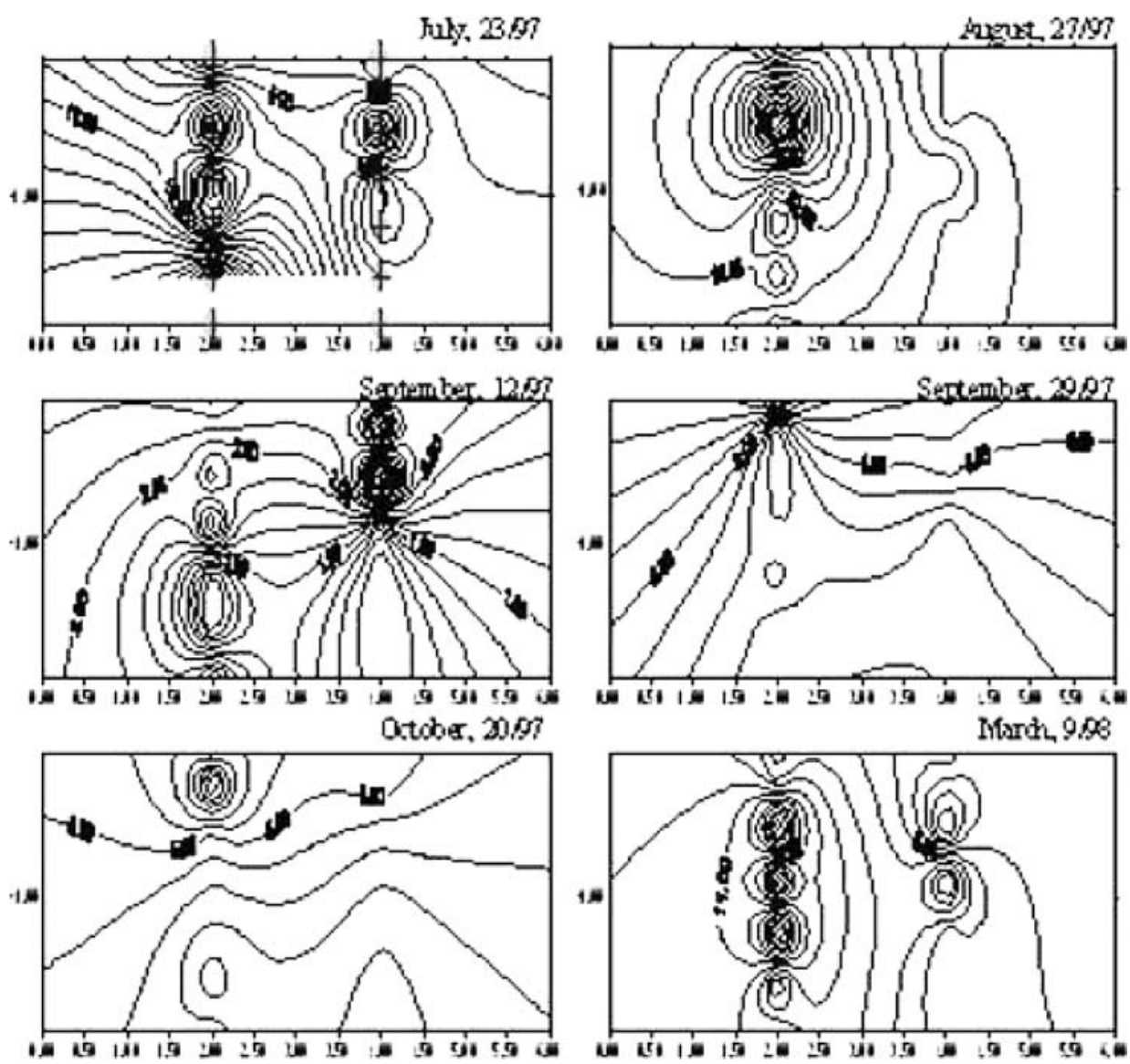

Figure 9. Uranium vertical distribution from July 1997 to March 1998.

uranium was gathered in fine texture discontinuous lens, $\mathrm{pH}$ ranging between 6.08.0 and a $53.3 \mathrm{~cm}^{2} / \mathrm{g}$ surface area. In that day, the rainy season started, causing a high uranium sorption process. On August 27/1997, a desorbing trend appeared due to the effect of the recharge in the rainy season. In this case, the uranium appears to have flowed downwards. On September 12/1997, the uranium concentration decreased and on September 29/97 it increased, after that, it was transported towards lower layers. On October 20/1997, the uranium began to accumulate and move slowly. Finally, in March/1998 the uranium presented a similar behavior to that in July, perhaps because it had been affected by the new agricultural cycle, Figure 9.

\subsubsection{Phosphate}

As in the case of uranium, the vertical distribution of phosphates was observed from July 1997 to March 1998, during six sampling campaigns. There was a decrease in phosphates from $0.6 \mathrm{mgL}^{-1}$ to $0.1 \mathrm{mgL}^{-1}$, between $15 \mathrm{~cm}$ to $180 \mathrm{~cm}$. This decrease 

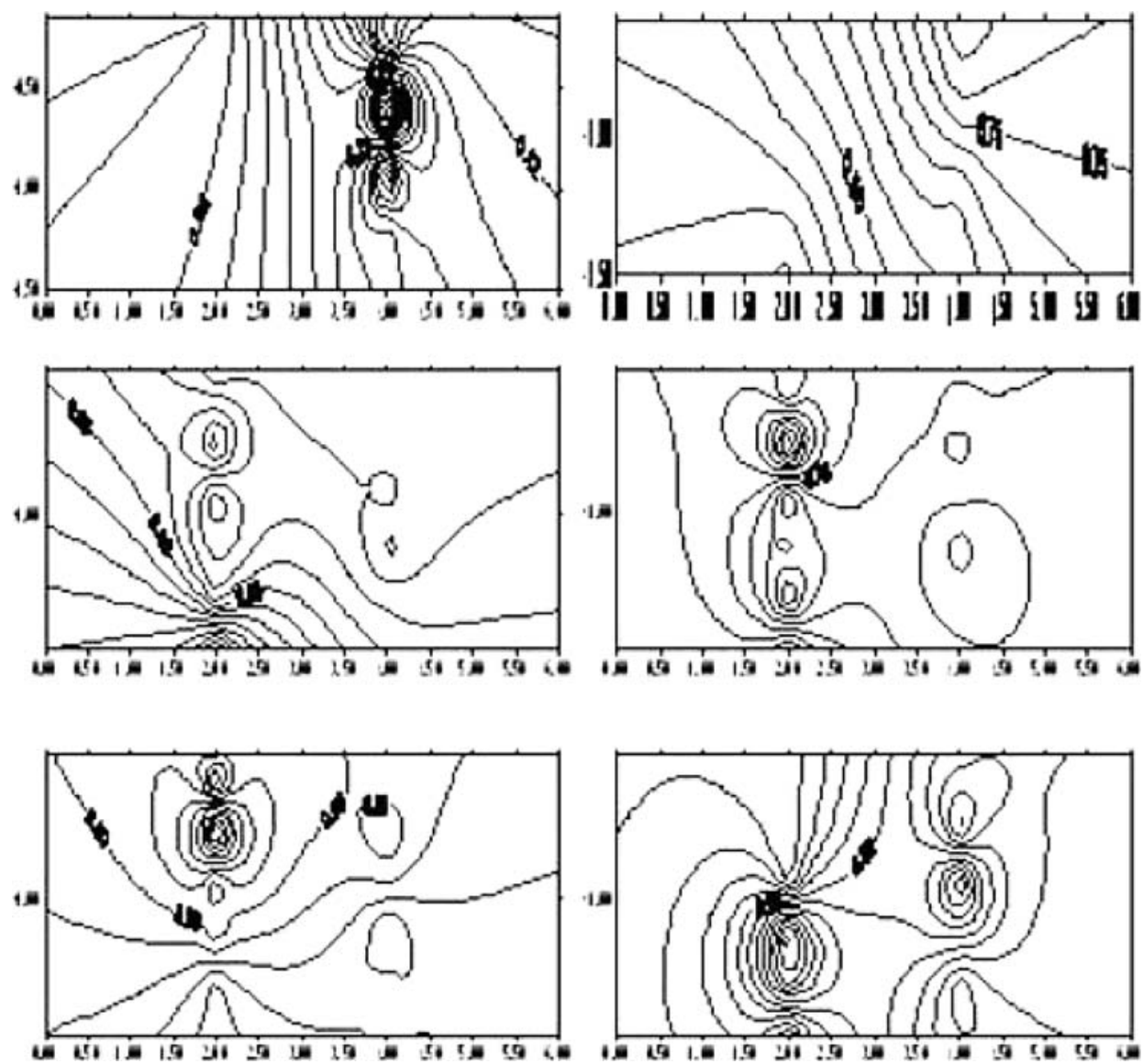

Figure 10. Phosphate vertical distribution from July 1997 to March 1998.

resulted from the calcium phosphate precipitation at these $\mathrm{pH}$ conditions. It is interesting to remember that phosphate fertilizers do not dissolve immediately after their application. The dissolution is very slow and it occurs in the rainy season. In the sampling taken on July 23/1997, the phosphate accumulated ion was detected; on August 1997, the increase in phosphate dissolution was found because of the rain. The analyses of samples taken on September 12 and 29/1997 revealed that the phosphates began to accumulate in the $60 \mathrm{~cm}$ pellet layer of the soil, Figure 10.

\subsubsection{Nitrate}

In the case of nitrate, the vertical distribution was observed from July 1997 to March 1998, during six sampling campaigns. There was a decrease of nitrates from $10 \mathrm{mgL}^{-1}$ to $2.20 \mathrm{mgL}^{-1}$ between $15 \mathrm{~cm}$ to $180 \mathrm{~cm}$. Such a decrease ocurred because nitrate is one of the most mobile ions in water. It is interesting to remember that nitrate fertilizers dissolve immediately after their application. The dissolution is very fast and the nitrate moves quickly. The samplings taken on July 23/1997 

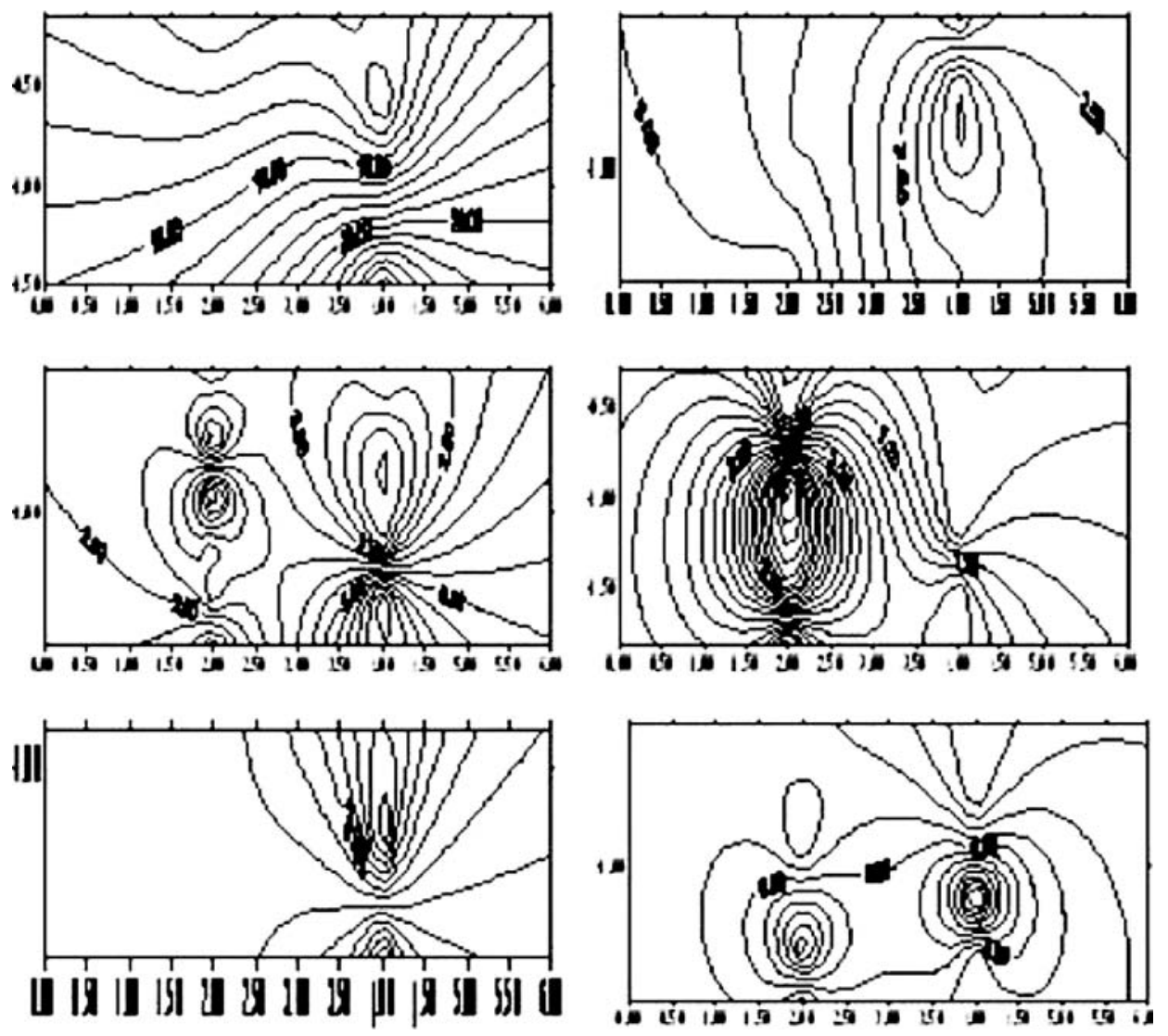

Figure 11. Nitrate vertical distribution from July 1997 to March 1998.

showed that the nitrates were dispersed; on August 1997, it was found that the nitrate dissolution increased, due to rain. On September 12 and 29/1997 it was found that once again the nitrate began to move once again because there had been a new application of nitrate fertilizer, Figure 11.

The entries of phosphate and uranium into a vadose zone were quantified in accordance with the phosphate fertilizers provided, because this was the only entrance path from these ions to the soil. The quantity of phosphate was $443 \mathrm{gkg}^{-1}$ and of uranium was $198 \mathrm{mg} \mathrm{kg}^{-1}$, with an application dose of $198 \mathrm{kgHa}^{-1}$. From the total phosphate, a fraction was assimilated by the crops (15-20\%), while the rest remained in the interphase vadose zone-water. This amount can move and go through physico-chemical processes. The data obtained allowed us to verify that approximately $90 \%$ of the phosphate was retained in the soil and only a small portion was able to migrate through the vadose zone.

The chemical speciation diagrams showed that the main factors that control the migration of phosphates and uranium through the vadose zone are the $\mathrm{pH}$, and the 
phosphate, bicarbonate and uranyl concentration. Likewise, it is important to point out that the processes involved are not separated and that they occur in the vadose zone.

The uranium concentration in the soil oscillates between 16 and $51 \mathrm{mg} \cdot \mathrm{kg}^{-1}$, which indicates that the soil is contaminated, because the recommended concentration is $2.1 \mathrm{mg} \cdot \mathrm{kg}^{-1}$. The uranium concentration in the soil water is between 2.5 and $10.3 \mathrm{mg} \cdot \mathrm{kg}^{-1}$, these values rebased the recommended concentration for water.

\section{Conclusions}

The uranium, phosphate and nitrate concentrations in the soil water exceed the Mexican and EPA regulations, and in groundwater they present values below those stipulated in both standards.

The identification of species that form the uranyl, as well as the rest of the chemical elements present in the water was accomplished. In the case of soil water, the identified soluble species were $\mathrm{UO}_{2}\left(\mathrm{CO}_{3}\right)_{2}{ }^{2-}, \mathrm{UO}_{2}\left(\mathrm{CO}_{3}\right)_{3}{ }^{4-}$, $\mathrm{UO}_{2}\left(\mathrm{HPO}_{4}\right)_{2}{ }^{2-}, \mathrm{UO}_{2}\left(\mathrm{CO}_{3}\right)_{2}{ }^{2-}$ and $\left(\mathrm{UO}_{2}\right)_{2}(\mathrm{OH})_{3} \mathrm{CO}_{3}{ }^{-}$; the insolubles species were $\left(\mathrm{UO}_{2}\right)_{3}\left(\mathrm{PO}_{4}\right)_{2} \cdot 4 \mathrm{H}_{2} \mathrm{O}_{(c)}$ and $\mathrm{CaUO}_{4(c)}$.

The uranium retention is very effective in a vadose zone which is a multilayer with clay lens discontinuous having low permeability. These lenses can act as barriers against contaminant infiltration resulting from agricultural activities.

\section{Acknowledgement}

Financial support for this research was provided by Consejo Nacional de Ciencia y Tecnología (CONACyT, $0391 \mathrm{P}-\mathrm{T}$ ) and Instituto Nacional de Investigaciones Nucleares (ININ, IB-258). We would like to thank to I. Puigdomenech for the copy of the MEDUSA application used in this study.

\section{References}

APHA, AWWA, WEF (1995). Standard Methods for the examination water and wastewater, 19th edn, Washington, D.C.: APHA, AWWA \& WEF.

Barisic, D., Lulic, S., \& Miletic, P. (1992). Radium and uranium in phosphate fertilizers and their impact on the radioactivity of waters. Water Resource, 26, 607-611.

Bayliss, P., Sabina, S.A., Anderson, \& R.y Cesbrón F. (1986). A minerals power diffraction file, databook, internacional centre for diffraction. Editorial Staff U.S.A. Joint Committee on Powder Diffraction Standards (JCPDS).

Custodio, E., \& Llamas, M.R. (1983). Hidrología subterránea editorial omega (2359 p.). Barcelona España. 
Deutsch, W.J. (1997). Groundwater geochemistry, fundamentals and applications to contamination (221 p). New York, USA: Lewis Publishers.

Diario Oficial de la Federación (DOF), 13 de Diciembre (1989). Criterios Ecológicos de Calidad del Agua. México

Domenico, P.A., \& Schwartz, F.W. (1998). Physical and chemical hydrogeology, (2nd ed.) New York USA: John Wiley \& Sons. Inc.

Drever J.I. (1988). The geochemistry of natural waters (Chapter 15, 437 p). Englewood Cliffs, New Jersey: Prentice Hall.

Eghball, B., Binford, G.D., \& Baltensperger, D.D. (1996). Phosphorus movement and adsorption in a soil receiving long term manure and fertilizer application. Journal of Environment Quality, 25, 1339-1343.

Esteller, M.V., \& Andreu, J.M. (2005). Antropic effects on hydrochemical characteristics of the Valle de Toluca aquifer (Central Mexico). Hydrogeology Journal, 13, 378-390.

Fetter C.W. (1993). Contaminant Hydrogelogy (Chapter 6, 243 p). New York USA: Macmillan Publishing Company.

Freeze, R.A., \& Cherry, J.A. (1979). Groundwater englenwood cliffs. N.J. USA: Prentice-Hall, Inc.

Geng, Q.Z., Girard, G., \& Ledoux, E. (1996). Modeling nitrogen cycle and nitrate transfer in regional hydrogeologic systems. Groundwater, 34, 293-304.

Gerritsen, R.G. (1993). Prediction of travel times of phosphate in soils at a disposal site for wastewater. Water Resource, 27, 263-267.

Goldberg, S., \& Sposito, G. (1984). Uranium solution at low temperature with applications to sedimentary deposits. Geochimica et Cosmochimica Acta, 42, 547-569.

Hall, D.W. (1992). Effects of nutrient management on nitrate levels in groundwater near Epharata Pennsylvania. Groundwater, 30, 720-730.

He, Z.L., Wilson, M.J., Campell, C.O., Edwards, A.C., \& Chapman, S.J. (1995). Distribution of phosphorus in soil aggregate fractions and its significance with regard to phosphorus transport in agricultural runoff. Water, Air and Soil Pollution, 83, 69-84.

Jabro, J.D., Toth, J.D., Dou, Z., Fox, R.H., \& Fritton, D.D. (1996). Evaluation of nitrogen versión of LEACHM for predicting nitrate leaching. Soil Science, 160, 209-217.

Journel, A.G. (1989). Fundamentals of geostatistics in five lessons, short course geol (Ser., Vol. 8). Washington, D.C.: AGU.

Kohler, M., Curtis, G.P., \& Kent, D.B. (1996). Experimental investigation and modeling of uranium (VI) transport under variable chemical conditions. Water Resources Research, 32, 3539-3551.

Linsalata, P. (1989). Exposure to long-lived members of the uranium and thorium decay chains. Radiation Physics and Chemistry, 34, 241-250.

Plummer, L.N., Prestemon, E.C., \& Parkhurst, D.L. (1991). An interactive Code NETPATH for modeling net geochemical reactions along a flow path. U.S. Geological Survey Water Resources Investigations, Reports, 91-4078, 227 p.

Puigdomenech, I. (2004). Make Equilibrium Diagrams Using Sophisticated Algorithms (MEDUSA) program. Inorganic Chemistry Department, Royal Institute of Technology, 100 44, Stockholm, Sweden. http://web.telia.com/ u15651596/.

Pulido, J.S., Aguilar, A.G., \& Vázquez, A. (1992). Química de suelos. México: Universidad Autónoma de Chapingo.

Romero, G.E.T., Solache, M., Iturbe, J.L., \& Ordoñez, E. (1995). Uranium in phosphate rock and derivates. Journal of Radioanalytical Nuclear Chemistry, 189, 301-306.

Rothbaum, H.P., McGaveston, D.A., Wall, T., Johston, A., \& Mattingly, G. (1979). Uranium accumulation in soils from long continued applications of superphosphate. Journal of Soil Science, 30, $147-153$

Sharpley, A.N., Smith, S.J., \& Nancy, J.W. (1987). Environmental impact of agricultural nitrogen and phosphorus use. Journal of Agriculture Food and Chemisry, 35, 812-817. 
Taylor, S.R., \& McClennan, S.M. (1985). The Continental Crust: its composition and evolution. Blackwell Scientific.

USEPA. (1996). National primary drinking water regulations for radionuclides. Proposed rules. Washington D.C. 570 9-71-700. Report.

Vighi, M., Soprani, S., Puzzarini, P., \& Menghi, G. (1991). Water quality phosphorus loads from selected watersheds in the drainage area of the northern adriatic sea. Journal of Environment Quality, 20, 439-444.

World Health Organization, OMS (1993). Guidelines for drinking water quality. Ginebra: WHO Publications.

Zielinski, R.A., Asher, B.S., Meier, A.L., Johnson, C.A., \& Szabo, B.J. (1997). Natural or fertilizer derived uranium in irrigation drainage: a case study in southeasters Colorado, USA. Applied Geochemistry, 12, 9-21. 